\title{
Scientific literacy profile in biological science of high school students
}

\author{
Novaristiana R a,1,", Yudi Rinanto a,2, Murni Ramli a,3 \\ a Department of Biology Teacher Education, Faculty of Teacher Training and Education, Universitas Sebelas Maret, Jalan Insinyur Sutami No.36 A \\ Kentingan, Jebres, Surakarta, Central Java 57126, Indonesia \\ 1 novaristyas@gmail.com*; 2 yudi.rinanto@staff.uns.ac.id; ${ }^{3}$ mramlim@staff.uns.ac.id \\ * corresponding author
}

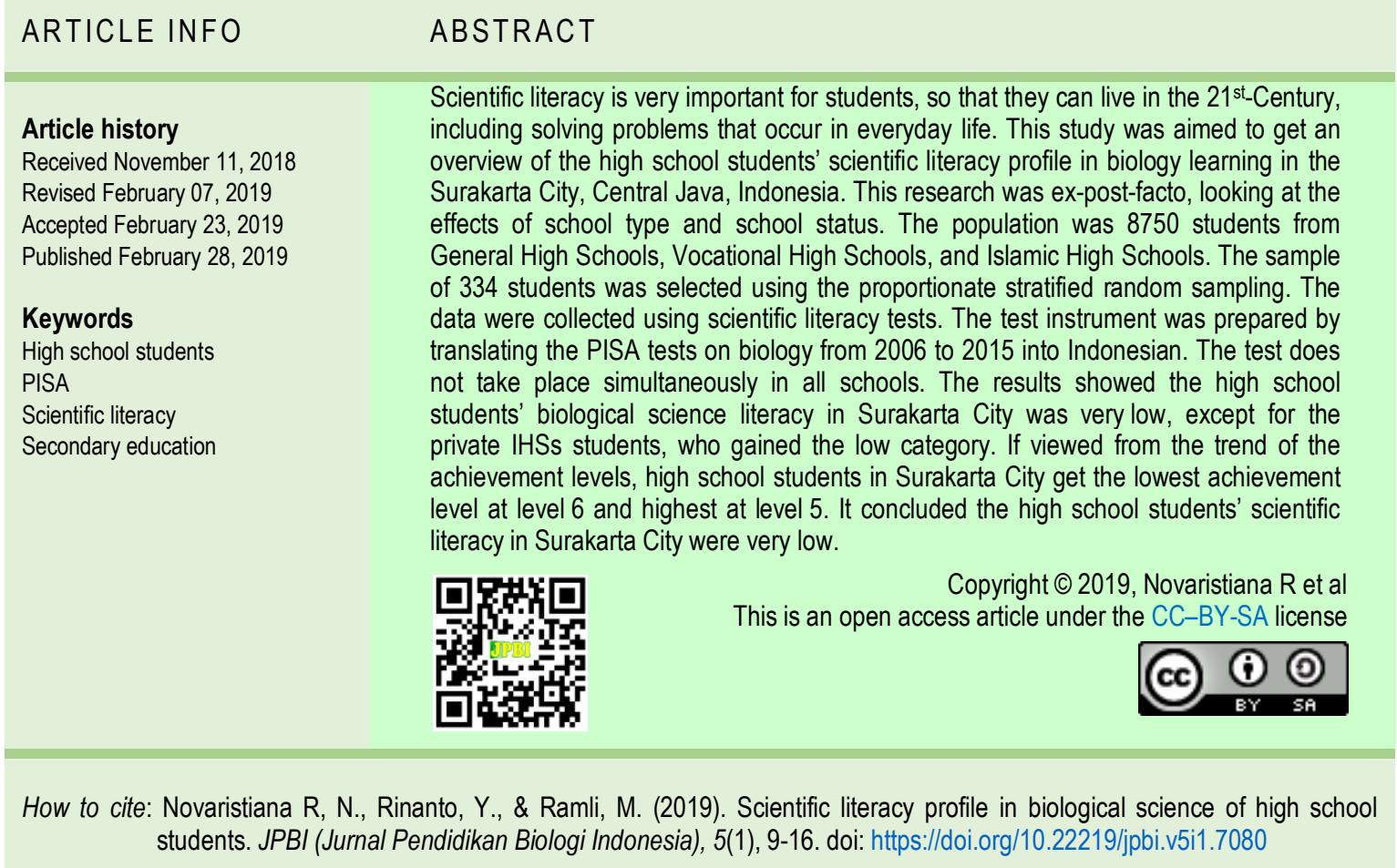

\section{INTRODUCTION}

Indonesia took the PISA test since 2000, which held every three years. However, from 2000 to 2015, scientific literacy skills of Indonesian students have always been ranked lower other countries. In 2000, 2003, 2006, 2009, 2012, and 2015 respectively, Indonesian students were ranked 38 out of 41 countries, 38 out of 40 countries, 50 out of 57 countries, 60 out of 65 countries, 64 from 65 countries (Bagiarta, Karyasa, \& Suardana, 2015), and 64 out of 72 countries (OECD, 2015).

The low scientific literacy skills of Indonesian students are concerning matter given the importance of scientific literacy skills in the $21^{\mathrm{st} C e n t u r y . ~ S c i e n c e ~ l i t e r a c y ~ c a n ~ b e ~ t h e ~ d e t e r m i n a n t ~ o f ~ s t u d e n t s ' ~ a b i l i t y ~ t o ~ s o l v e ~}$ problems occurring in everyday life, both those individual and global problems (Choi, Lee, Shin, Kim, \& Krajcik, 2011). Scientific literacy is very important to understand and develop the technology in the era of globalization. Adisendjaja (2010) explained mastering the scientific literacy is important for students because they closely related to students' understanding of health, environment, economy, and the problems of society in this era, which depends on the progress of science and technology. 
Scientific literacy is the soul of knowledge, ways of life, and tools used for individuals and international competitions (McFarlane, 2013). According to the OECD (2016), scientific literacy is the persons' ability to involve themselves in solving scientific problems with scientific ideas in the reflective society.

Scientific literacy is the ability to understand scientific processes and scientific knowledge in everyday life (Fives, Huebner, Birnbaum, \& Nicolich, 2014). Scientific literacy skills equip students with the knowledge and skills to solve problems occurring in everyday life, both individual and global problems (Choi et al., 2011). Lederman, Lederman, and Antink (2013) stated the scientific literacy affects the decision-making to solve problems occurring within individuals or society. Gormally, Brickman, and Lut (2012) stated the scientific literacy emphasizes individual science knowledge to solve the problems in the real world.

One factor causing the students' low scientific literacy is because they are not used to solving the problems or tests related to science process skills which are the major part of scientific literacy (Odja \& Payu, 2014). Majority of the learning process only takes place in the process to transfer the knowledge from the teachers to the students (Suciati et al., 2014) and encourages them to memorize the materials (Pantiwati \& Husamah, 2014). So they are less trained to master the process skills and cause their low scientific literacy skills (Ariyanti, 2016).

Other factors influencing the scientific literacy of Indonesian students are: (a) Curriculum and education system; (b) Selection of learning methods and models by the teachers; (c) Learning facilities; (d) Learning resources; (e) Teaching materials; and others (Kurnia, Zulherman, \& Fathurohman, 2014). Demir (2016) expressed another opinion about the factors influencing the acquisition of scientific literacy, such as (a) students' economic status; (b) students' social status; and (c) students' attitudes in school, which include their learning activities, learning outcomes in school, and students' views on education or activities at the school.

People can be categorized as the scientifically literate if they master the scientific literacy competencies. OECD (2015) stated the scientific literacy competencies comprises the three criteria: (a) explaining the phenomena scientifically; (b) evaluating and designing scientific investigations; and (c) interpreting scientific evidence and data. Besides dividing scientific literacy into 3 competencies, the OECD also divided the levels scientific literacy mastery. It is divided into 7, from levels 1 to 7 . The higher the level, the more able students' scientific literacy in abstract and complex matters. Conversely, the lower the level, the more able students' scientific literacy in the contextual and simple matter.

The PISA test assesses the students' literacy skills including 4 aspects: context, content, competence, and attitude. Scientific literacy skills of Indonesian students are unsatisfactory ranked lower internationally. They achieved the lowest level (level 1). The PISA scores showed the Indonesian students just arrived at the ability to recognize the basic facts, but they are not yet able to communicate, relate, and apply their skills to scientific topics.

The PISA test has been used several times by Indonesian researchers to assess the students' scientific literacy. Besides using the translated PISA instruments, they also developed their scientific literacy assessment instruments based on the OECD's scientific literacy competencies.

Suciati et al (2014) have composed the instruments based on the OECD criteria to assess students' scientific literacy in Biology learning in several high schools in Surakarta and surrounding areas. The results showed the students' low scientific literacy abilities. But the number of samples used was relatively low to represent the entire population of high school students in Surakarta City. So, it cannot be used to generalize the achievements of scientific literacy of high school students in Surakarta City.

Recently, there are no comprehensive data about the status of the high-school students' scientific literacy in Surakarta City. So, it is necessary to conduct research on that matter, which will be useful to improve the strategies to improve students' scientific literacy in Surakarta in particular, and Indonesia in general. The objectives of this study were: (a) to get an overview of the scientific literacy profile of high school students in Surakarta City based on the type of school; and (b) to get an overview of the scientific literacy profile of high school students in Surakarta City based on school status.

\section{METHOD}

This research was an ex-post-facto research. The population was the high school students in Surakarta City. Populations originating from VHSs were reduced and selected from VHSs which has integrated science or Biology subjects. The population (in 2017) was 8750 students. The samples were determined by using the formula from Isaac and Michael with $a=5 \%$. The total samples of 334 students were selected using the proportionate stratified random sampling. The sample of high school students was 218 students from 4 public GHS and 4 private GHS in Surakarta City. The vocational students were 80 students randomly selected from 2 public VHS and 3 private VHS. The samples from the Islamic high schools were 36 students randomly selected from 1 public IHS and 1 private IHS. 
Based on the students 'admission data of public GHSs in Surakarta City in 2015-2017, one of the GHS chosen was a favorite school. But the other three were not. The favorite one is the first rank in the national exam in the city Surakarta. While the private GHSs selected were ranked as top 15 in admission data in Surakarta City.

The data were collected using scientific literacy tests. Scientific literacy assessment instruments in biological science were produced by translating and selecting questions from the 2006-2015 PISA tests. The PISA test has been tested for its validity and reliability so that for the sake of research the instrument is only validated based on expert judgment. The instrument readability also tested on some 15 to 17 -year-old students. The question items were 25 in multiple-choice questions and 5 in the "yes/no" questions.

The students' raw scores were changed to 100 standard scores with the formula proposed by Purwanto (2009) as seen at Formula 1. The standardized students' scores then categorized based on the level of scientific literacy from PISA, and PISA scientific literacy competencies.

$$
N P=\frac{R}{S M} \times 100
$$

Information: NP = Standardized Students' Score; R = Raw Students' Score; SM = Students' Maximum Score; 100 = Constanta

The students' score then categorized from very low to very high by referring to intervals and criteria in Table 1. The results were tested for differences using the Kruskal-Wallis Test. The Kruskal-Wallis test was used because data were not normal from the normality test.

Table 1. The criteria for students' scientific literacy in biological science in Surakarta

\begin{tabular}{cc}
\hline Interval & Criteria \\
\hline $86-100$ & Very High \\
$76-85$ & High \\
$60-75$ & Mediocre \\
$55-59$ & Low \\
$\leq 54$ & Very Low \\
\hline
\end{tabular}

(Source: modified from Purwanto, 2009)

\section{RESULTS AND DISCUSSION}

Figure 1 showed the achievements of scientific literacy of high school students in all types and status of schools in Surakarta City. If viewed from the types of school, the order from high to low was IHSs, GHSs, and VHSs students. The Kruskal-Wallis test showed the significance value of 0.000 (sig. $<0.05$ ) which means there was no significant difference in the achievements of scientific literacy between the students from all types of schools.

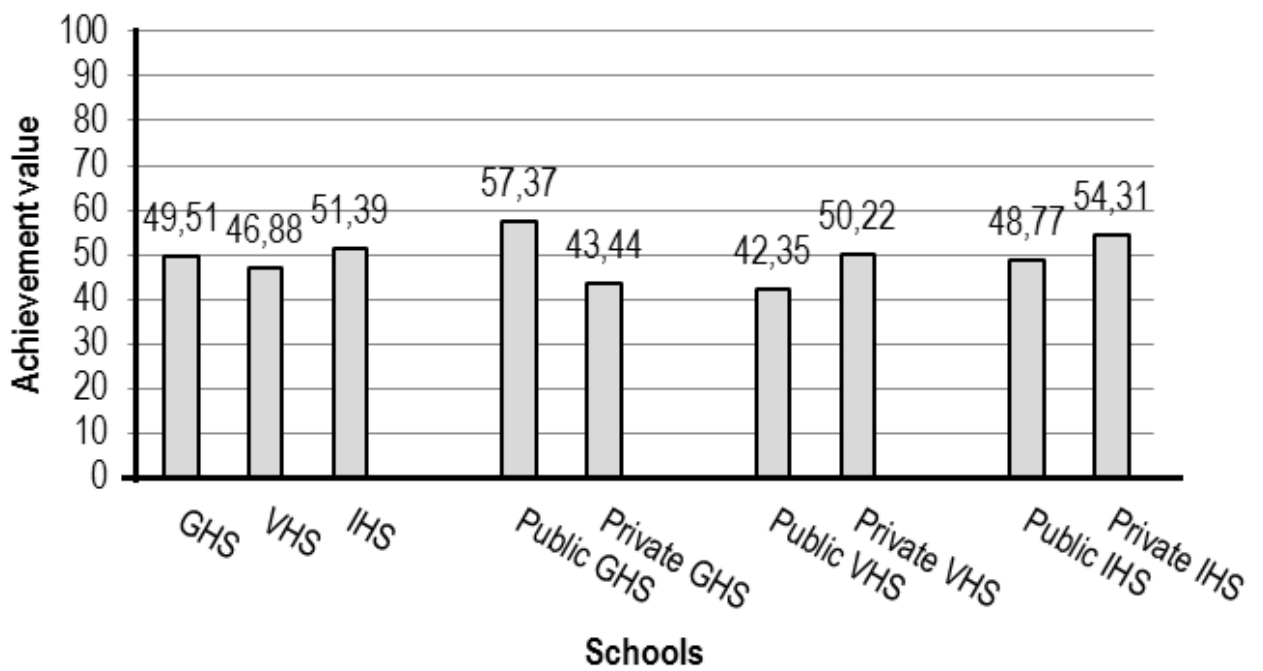

Figure 1. Achievement of scientific literacy of high school students in Surakarta City

Figure 2 showed the achievement of students' scientific literacy in the three test-groups (GHSs, VHSs, and IHSs students in Surakarta City) vary at each level. GHSs and VHSs students achieved mediocre results for levels 1 and 5 while other levels were very low. The IHSs students also got mediocre results for levels 1,2 , and 
5 , and very low results for levels 3,4 , and 6 . If viewed from the achievements of scientific literacy competencies, GHSs students got very low results in all three competencies, the same thing for VHSs students. For IHSs students, the achievement for competencies A and B were very low, and competency $\mathrm{C}$ was low.

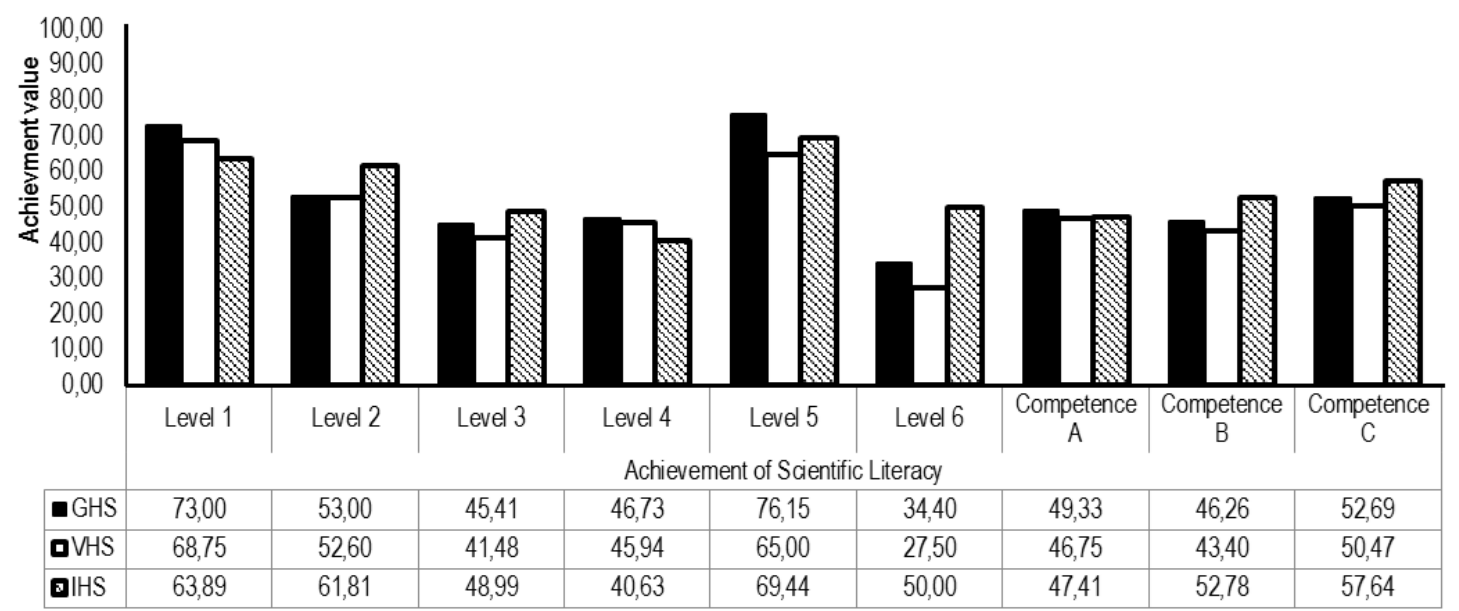

Figure 2. Levels of students' scientific literacy in biological science based on the types of the schools

Figure 3 showed the public GHSs students got high result for level 1 , very high for level 5 , mediocre for levels 2 and 4 , low for level 3 , and very low at level 6 . While private GHSs got mediocre result for levels 1 and 5 , and very low for level $2,3,4$, and 6 . The private GHSs students were outperformed by public GHSs students in all three scientific literacy competencies. The achievement of science literacy competencies of public GHSs students was mediocre for competency $\mathrm{C}$, low for competency $\mathrm{A}$, and very low for competency $\mathrm{B}$. While private GHSs got very low criteria for all competencies.

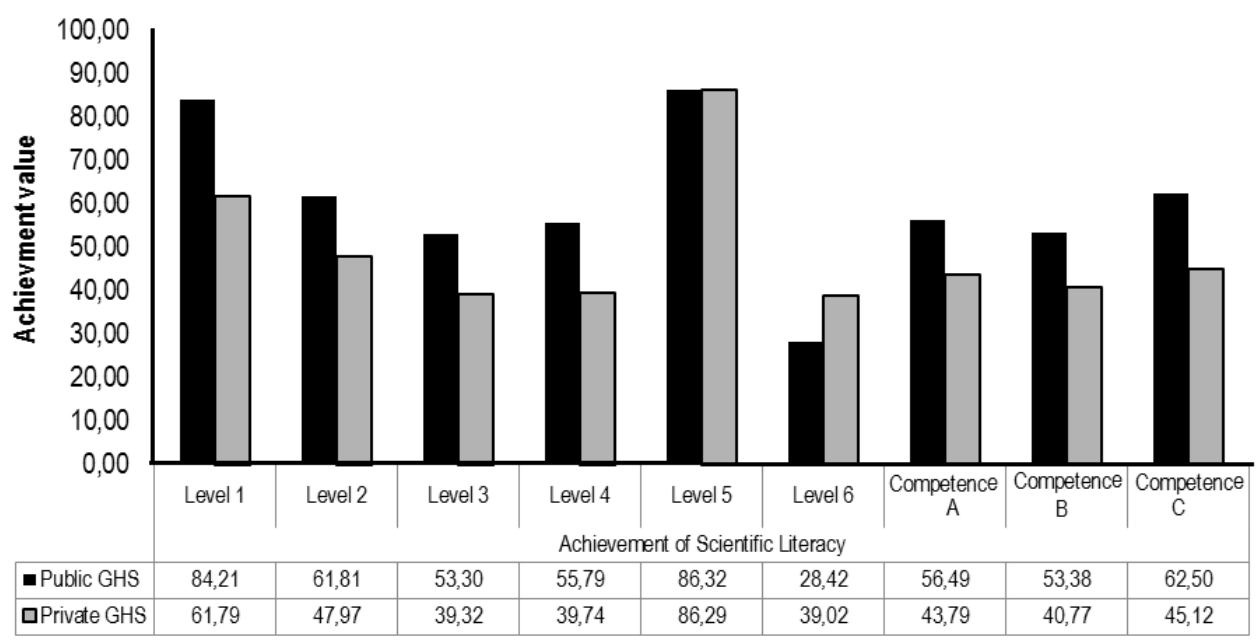

Figure 3. Levels of GHS students' scientific literacy in biological science based on the schools' statuses.

Figure 4 showed the public VHSs students got mediocre criteria only for level 1 , low for level 5 , and very low for level 2, 3, 4, and 6. While for private VHSs students got mediocre result for levels 1 and 5 , and very low for level $2,3,4$, and 6 . Both public and private VHSs students got very low results for each of scientific literacy competencies.

Figure 5 showed the public IHSs students got mediocre for level 1, low for levels 2 and 5, and very low for level 3,4 , and 6 . While the private IHSs students got high for level 5 , mediocre for levels 2 and 6 , low for level 1, and very low for levels 3 and 4. Public IHSs students got very low for every scientific literacy competencies. But the private IHSs students got mediocre for competency $\mathrm{C}$, low for competence $\mathrm{B}$, and very low for competency $A$.

From the statistical analysis, it can be concluded that the achievement of students' scientific literacy in all types of school (GHSs, VHSs, and IHSs) in Surakarta City was not significantly different. In successions, the schools with the highest to the lowest scientific literacy achievement rates were IHSs, GHSs, and VHSs students. The IHS students got overall scientific literacy achievement of 51.39, the GHS students were 49.51, 
and VHSs students were 46.88. VHS students got the lowest position compared to GHSs and IHSs students. The low achievement in science literacy of VHSs students can be caused by a different curriculum. The curriculum for science subjects in VHS is tailored based on the vocational specialty chosen by the students. So, it's different from the biology curriculum in GHSs and IHSs.

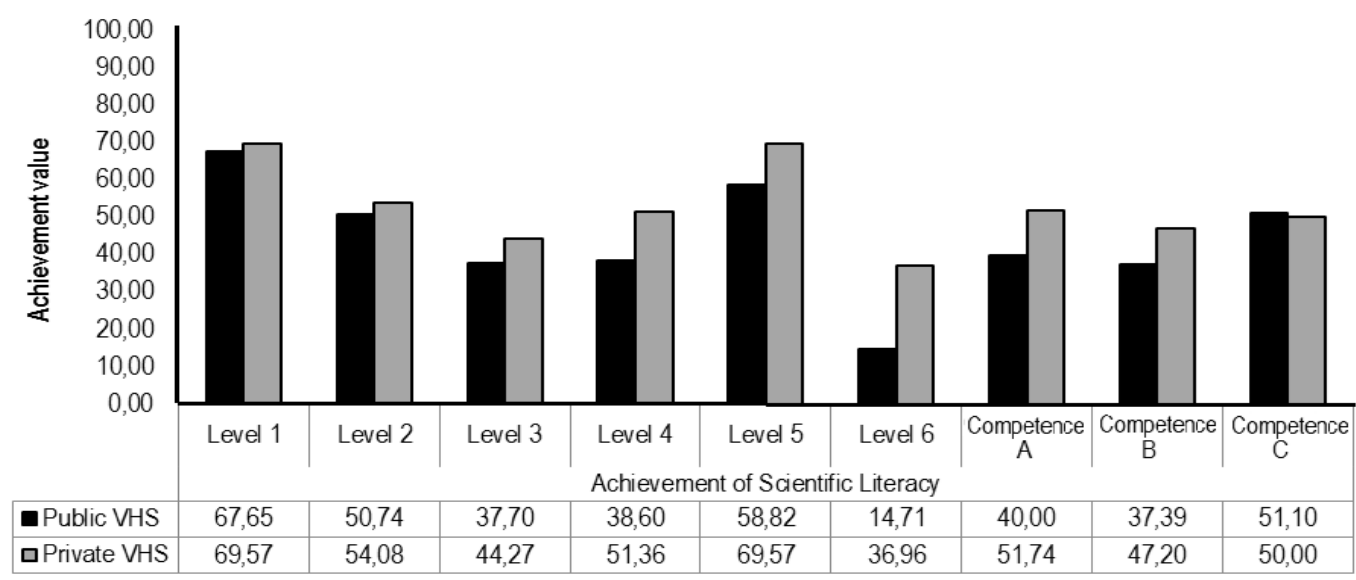

Figure 4. Levels of VHS students' scientific literacy in biological science based on the schools' statuses.

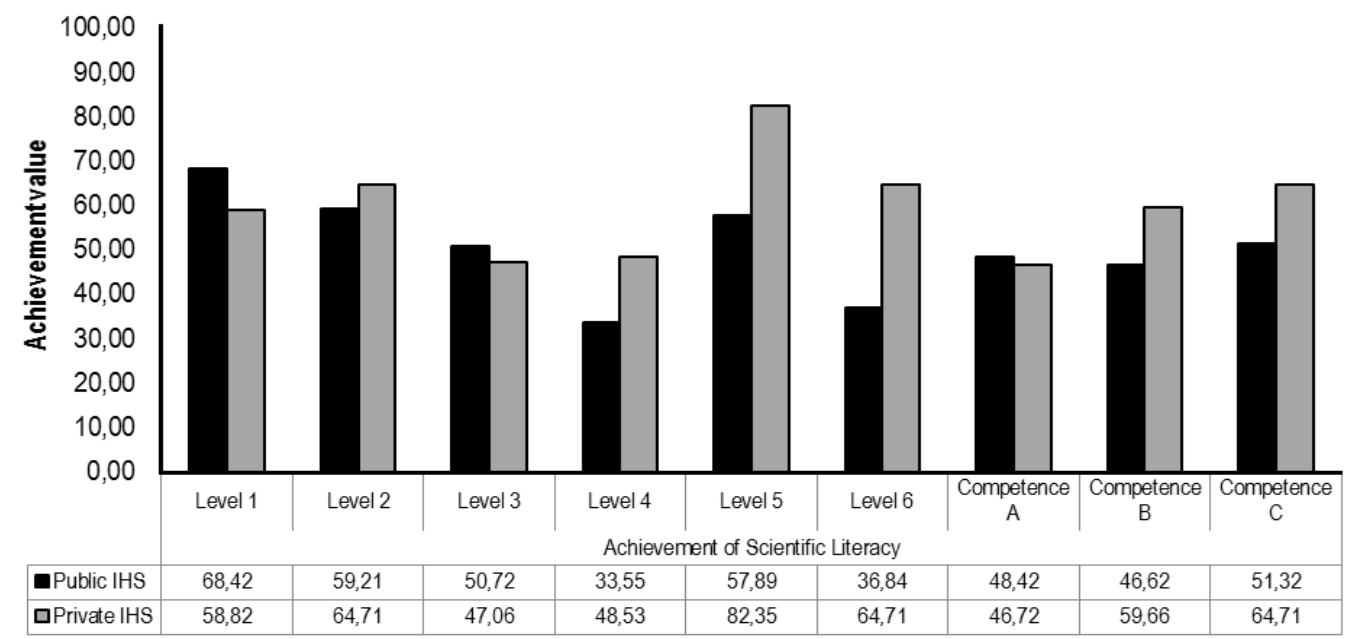

Figure 5. Levels of IHSs students' scientific literacy in biological science based on the schools' statuses.

According to Purnomo and Munadi (2005), VHSs are the vocational educations which prioritize students' competency in certain types of work (skill specialization). Although VHSs students are equipped with basic skills to adjust to the development of science and technology, in this study it was found the achievement of scientific literacy levels and competencies was very low and the lowest compared to other types of secondary educations.

The high average value of achievement for IHSs students can be caused by the number of sample groups for IHSs were less than those of GHSs and VHSs. This error was a sampling error. (Kahar, 2010)explained the smaller the number of samples can increase the occurrence of sampling errors in the survey. The number of samples from IHSs students is less than GHSs and VHS students caused by the IHSs students were less than GHSs and VHSs students. Statistically, the sample size for IHSs students for this study was in accordance with the theory of sampling techniques applied by researchers.

If viewed from the schools' statuses, there were differences. Public GHSs students got higher achievements than the private GHSs students. The achievement for public and private GHSs were 57.37 and 43.44 respectively. These results were in accord with Rianti (2016) and Aini and Syarifuddin (2016). They stated the public GHSs students, on average, got higher achievement in the mastery of scientific literacy compared to the private ones.

Aini and Syarifuddin (2016) studied the scientific literacy of eleventh graders in Kisaran City. While Rianti (2016) has done it on ninth graders in Pringsewu District, Pagelaran Regency. Aini and Syarifuddin (2016) argued the differences in scientific literacy mastery came from the fact the public GHSs have better facilities to support science learning than the private ones. But different results shown by IHSs and VHSs students. Public 
VHSs students got 42.35 and the private VHSs students were 50.22. Public IHSs got 48.77 and 54.31 for the private IHSs students. It showed the private VHSs and IHSs students have the better mastery of scientific literacy than the public VHSs and IHSs students.

Those results showed the statuses of the schools did not become the defining factor for the mastery of scientific literacy. Kurnia et.al. (2014) stated some factors affect the mastery of scientific literacy, such as the curriculum and education system, selection of teaching models and methods by the teachers, learning facilities, learning material, learning resources, etc.

If we categorized the levels of scientific literacy mastery, we can see the trend in the students' mastery. The test groups got the highest mastery on the levels 1 and 5 , and the lowest one on level 6 .

On level 1, all test groups got mediocre results, except for public GHSs (high) and private IHSs (low). These results were in confirmed the Indonesian students' PISA results in previous years, which were at the low category and the majority were on the level 1. Level 1 scientific literacy means the students' understanding was limited and only able to implement their understanding in small and/or familiar situations. It means they were only able to offer the scientific explanation based on the given facts (OECD, 2007). Toharudin, Hendrawati, and Rustaman (2011), explained the scientific literacy skills of Indonesian students limited to identify basic facts, but they cannot communicate their understandings, interconnect the concepts, and apply their understanding to scientific topics.

On level 2, in general, all groups got results in the low category. Whereas on the levels 3 and 4, all group showed results in the low category. These results showed the students' mastery of scientific literacy on level 2, 3 , and 4 , were at the low category. For level 5 , all groups showed mediocre results. But students from public GHSs and private IHSs got the high results, and for public IHSs got the low category. In this level, all groups gained better results compared with other levels. This was an anomaly, considering the low mastery on the level 2, 3, and 4. Odja and Payu (2014), argued the low students' mastery of scientific literacy was because they were not used to solving the problems or questions related to science process skills. The anomaly for the level 5 occurred because the questions posed were familiar to the students. The questions were about reading and inferring the graphs. Slamet and Maarif (2014) argued one of the most familiar types of test for the students was inferring and analyzing the graphs, diagrams, or pictures. The question item to assess the level 5 was the question no. 7. That question assesses the students' mastery at level 5 and competency $C$. From that question we can assess the students' skill to analyze the complex data and find the right conclusion (OECD, 2016).

At level 6, most of the test groups got the result in the low level, except for the private IHSs students (mediocre). According to PISA (OECD, 2016) at level 6 students should be able to apply interdisciplinary scientific ideas and interrelated concepts. They also able to make hypotheses to explain scientific events and processes, and arrange scientific predictions using procedural and epistemic knowledge. In interpreting data and evidence, they can distinguish between the relevant and irrelevant information and can use the knowledge got outside the school. They can also distinguish scientific and non-scientific arguments and can evaluate the design for the experiments, scientific studies, and scientific simulations. The results showed the students' mastery of level 6 scientific literacy skills was low except for the private IHSs students (mediocre).

Students' mastery of the competency (A) (explaining phenomena scientifically) can be classified as very low. Mastery of the competency (A) in private GHSs student test group was categorized as low. Students' mastery of the competency (B) (Evaluating and designing scientific investigations) were very low, except for the private IHSs test group (low). Students' mastery of the competency (C) (interpreting scientific evidence and data) were very low, except in the test group of public GHSs and private IHSs students. Based on the results, it can be concluded the students' mastery of scientific literacy competencies was very low. Ayuningtyas (2016) in their research also found the students' scientific literacy competencies were classified as very low for the ninth grader of Kedaton District in Bandar Lampung City.

The low mastery of scientific literacy among the high school students in Surakarta City was in accord with the opinion from Hobson (2008) and Odja and Payu (2014) which states, globally, scientific literacy was still low. Another study by Sudarisman et al. (2014) revealed the scientific literacy of students in several schools in Surakarta City was still unimpressive.

Scientific literacy can be improved through science-based education (Holbrook \& Rannikmae, 2016). Science education considers that education is obtained through science, not vice versa. Holbrook and Rannikmae (2016) stated science education include understanding the science, intellectual and communication skills, and student character. The application of science education to improve scientific literacy very depends on the curriculum assigned by the government. In Indonesia, the National Curriculum of 2013 has been implemented, with the learning process that emphasizes the students' active involvement in the learning process for independent knowledge building (Shafa, 2014). However, the application of said curriculum in the real situation has not been seen optimum. Some schools are not ready to implement the said curriculum (Permanasari, 2014) resulting in low students' mastery of scientific literacy. 
Students' mastery of scientific literacy can be improved through the improvement in the application of Curriculum of 2013 in the teaching and learning process. The learning process must use the scientific approach-based learning, so the students can master the scientific literacy competencies. In addition, practicums or experimentations are needed to improve students' scientific process skills. According to Arohman, Saefudin, and Priyandoko (2016) the lack of practicums or experimentations can hinder the students to master scientific literacy. To improve students' scientific literacy, the teachers can apply scientific approach based learning models, including problem-based learning, project-based learning, and discovery learning.

\section{CONCLUSION}

The results showed there were no significant differences in the mastery of scientific literacy in GHSs, VHSs, and IHSs students in Surakarta City. The achievement of biological science literacy in the three test-groups were classified as very low. Further researches are needed to analyze why scientific literacy of high school students in Surakarta City is low. Various stakeholders, such as education development experts, policymakers, and teachers should find way improve the methods of science teaching and learning. Teachers should familiarize the students with the PISA modeled tests, so they can compete in the PISA survey with students from other countries. Finally, the PISA modeled tests should be adopted by the teachers for the formative and summative assessments.

\section{REFERENCES}

Adisendjaja, Y. H. (2010). Analisis buku ajar biologi SMA kelas X di kota Bandung. Universitas Pendidikan Indonesia. Retrieved from https://www.scribd.com/doc/79336902/Analisis-Buku-Ajar-Biologi-Sma-Kelasx-Di-Kota-Bandungberdasarkan-Literasi-Sains

Aini, Y. R. F., \& Syarifuddin. (2016). Pengaruh status sekolah, rencana pendidikan setelah tamat SMA dan latar belakang pendidikan orang tua terhadap literasi sains siswa SMA kelas XI IPA Se-Kota Kisaran tahun pembelajaran 2015/2016. Jurnal Pelita Pendidikan, 4(1), 128-136. Retrieved from https:/l jurnal.unimed.ac.id/2012/index.php/pelita/article/download/3689/7324

Ariyanti, A. I. (2016). Pengembangan asesmen modifikasi nature of science literacy test (NOSLiT) untuk mengukur literasi sains siswa SMA (Uji coba di SMAN 1 Ngawi, SMAN 3 Madiun dan SMAN 1 Magetan). Published Magister Thesis at Pascasarjana Universitas Sebelas Maret. Pascasarjana UNS. Retrieved from https://digilib.uns.ac.id/dokumen/detail/50649/Pengembangan-Asesmen-Modifikasi-Na ture-of-Science-Literacy-Test-NOSLiT-untuk-Mengukur-Literasi-Sains-Siswa-SMA-Uji-Coba-di-SMAN-1Ngawi-SMAN-3-Madiun-dan-SMAN-1-Magetan

Arohman, M., Saefudin, S., \& Priyandoko, D. (2016). Kemampuan literasi sains siswa pada pembelajaran ekosistem. In Proceeding Biology Education Conference (Vol. 13, pp. 90-92). Surakarta, Central Java, Indonesia: Universitas Sebelas Maret. Retrieved from https://jurnal.uns.ac.id/prosbi/article/view/5662

Ayuningtyas, R. S. (2016). Profil kompetensi literasi sains siswa berdasarkan the programme for international student assesment (PISA) pada konten biologi. Published Undergraduate Thesis of Universitas Lampung. Universitas Lampung. Retrieved from http://digilib.unila.ac.id/23434/19/SKRIPSI TANPA BAB PEMBAHASAN.pdf

Bagiarta, I. N., Karyasa, I. W., \& Suardana, I. N. (2015). Komparasi literasi sains antara siswa yang dibelajarkan dengan model pembelajaran kooperatif tipe GI (group investigation) dan model pembelajaran inkuiri terbimbing (guided inquiry) ditinjau dari motivasi berprestasi siswa SMP. E-Joumal Program Pascasarjana Universitas Pendidikan Ganesha Program Studi Pendidikan IPA, 5(1), 1-11. Retrieved from http://oldpasca.undiksha.ac.id/e-journal/index.php/jurnal_ipa/article/view/1564

Choi, K., Lee, H., Shin, N., Kim, S., \& Krajcik, J. (2011). Re-conceptualization of scientific literacy in South Korea for the 21st century. Journal of Research in Teaching, 48(6), 670-697. doi: https://doi.org/ 10.1002/tea.20424

Demir, E. (2016). Characteristics of 15-year-old students predicting scientific literacy skills in Turkey. International Education Studies, 9(4), 99. doi: https://doi.org/10.5539/ies.v9n4p99

Fives, H., Huebner, W., Birnbaum, A. S., \& Nicolich, M. (2014). Developing a measure of scientific literacy for middle school students. Science Education, 98(4), 549-580. doi: https://doi.org/10.1002/sce.21115

Gormally, C., Brickman, P., \& Lut, M. (2012). Developing a test of scientific literacy skills (TOSLS): Measuring undergraduates' evaluation of scientific information and arguments. CBE Life Sciences Education, 11(4), 364-377. doi: https://doi.org/10.1187/cbe.12-03-0026 
Hobson, A. (2008). The surprising effectiveness of college scientific literacy courses. The Physics Teacher, 46(7), 404-406. doi: https://doi.org/10.1119/1.2981285

Holbrook, J., \& Rannikmae, M. (2016). The nature of science education for enhancing scientific literacy. International Journal of Science Education, 29(11). doi: https://doi.org/10.1080/09500690601007549

Kahar, M. (2010). Modul survei sampel. Jakarta. Retrieved from https://anzdoc.com/modul-survei-sampeloleh-muhardi-kahar.html

Kurnia, F., Zulherman, Z., \& Fathurohman, A. (2014). Analisis bahan ajar fisika SMA kelas XI di Kecamatan Indralaya Utara berdasarkan kategori literasi sains. Jurnal Inovasi Dan Pembelajaran Fisika, 1(1), 4347. Retrieved from https://ejournal.unsri.ac.id/index.php/jipf/article/view/1263

Lederman, N. G., Lederman, J. S., \& Antink, A. (2013). Nature of science and scientific inquiry as contexts for the learning of science and achievement of scientific literacy. International Journal of Education in Mathematics Science and Technology, 1(3), 138-147. doi: https://doi.org/10.18404/ijemst.19784

McFarlane, D. A. (2013). Understanding the challenges of science education in the $21^{\text {stt-Century: New }}$ opportunities for scientific literacy. International Letters of Social and Humanistic Sciences, 4, 35-44. doi: https://doi.org/10.18052/www.scipress.com/LSSHS.4.35

Odja, A. H., \& Payu, C. S. (2014). Analisis kemampuan awal liteasi sains siswa pada konsep IPA. In Prosiding Seminar Nasional Kimia (Vol. 01, pp. 40-47). Surabaya: Jurusan Kimia FKIP Universitas Negeri Surabaya. Retrieved from http://repository.ung.ac.id/get/karyailmiah/2750/analisis-kemampuan-awalliterasi-sains-siswa-pada-konsep-ipa-oleh-abdul-haris-odja-citron-payu.pdf

OECD. (2007). Volume 1: Analysis. In PISA 2006: Science competencies for tomorrow's world (p. 310). Paris, France: OECD Publishing. Retrieved from https://www.oei.es/historico/evaluacioneducativa/Informe PISA2006-FINALingles.pdf

OECD. (2015). PISA 2015 results in focus. Paris, France: OECD Publishing. Retrieved from https://www. oecd.org/pisa/pisa-2015-results-in-focus.pdf

OECD. (2016). PISA 2015 assessment and analytical framework: Science, reading, mathematic and financial literacy. Paris, France: OECD Publishing. Retrieved from http://www.oecd.org/publications/pisa-2015assessment-and-analytical-framework-9789264281820-en.htm

Pantiwati, Y., \& Husamah, H. (2014). Analisis kemampuan literasi sains siswa SMP Kota Malang. In I. W. Surata \& I. K. Suarnaya (Eds.), Prosiding Konferensi IImiah Tahunan Himpunan Evaluasi Pendidikan Indonesia (HEPI) (pp. 158-174). Denpasar-Bali, Indonesia: HEPI UKD Bali. Retrieved from http://research-report.umm.ac.id/index.php/research-report/article/view/526/748

Permanasari, A. (2014). Kurikulum 2013: Implikasinya dalam pembelajaran di sekolah, pendidikan profesi dan pendidikan tinggi. In Prosiding Seminar Nasional. Palopo: Universitas Cokroaminoto Palopo. Retrieved from https://journal.uncp.ac.id/index.php/proceding/article/view/218/207

Purnomo, E., \& Munadi, S. (2005). Evaluasi hasil belajar dalam implementasi kurikulum berbasis kompetensi di sekolah menengah kejuruan. Cakrawala Pendidikan, 24(2), 259-272. doi: https://doi.org/10.21831/ cp.v0i2.372

Purwanto, P. (2009). Evaluasi hasil belajar. Bandung: PT. Remaja Rosdikarya. Retrieved from https://books. google.co.id/books/about/Evaluasi_hasil_belajar.html?hl=id\&id=C6i_ZwEACAAJ\&redir_esc=y

Rianti, A. (2016). Profil kompetensi literasi sains siswa SMP kelas IX se-Kecamatan Pagelaran Kabupaten Pringsewu TA 2015/2016. Published Undergraduate Thesis of Universitas Lampung. Universitas Lampung. Retrieved from http://digilib.unila.ac.id/23062/20/SKRIPSI TANPA BAB PEMBAHASAN.pdf

Shafa. (2014). Karakteristik proses pembelajaran kurikulum 2013. Jurnal Dinamika IImu, 14(1), 81-96. doi: https://doi.org/10.1061/(ASCE)0733-9410(1991)117

Slamet, S., \& Maarif, S. (2014). Pengaruh bentuk tes formatif assosiasi pilihan ganda dengan reward dan punishment score pada pembelajaran matematika siswa SMA. Infinity Journal, 3(1), 59-80. doi: https://doi.org/10.22460/infinity.v3i1.p59-80

Suciati, S., Resty, R., Ita, W., Itang, I., Nanang, E., Meikha, M., ... Reny, R. (2014). Identifikasi kemampuan siswa dalam pembelajaran biologi ditinjau dari aspek-aspek literasi sains. In Seminar Nasional Pendidikan Sains IV 2014 (Vol. 1, pp. 1-8). Surakarta, Central Java, Indonesia: Universitas Sebelas Maret. Retrieved from http://jurnal.fkip.uns.ac.id/index.php/snps/article/view/5059

Toharudin, U., Hendrawati, S., \& Rustaman, A. (2011). Membangun literasi sains peserta didik. Bandung: Humaniora. Retrieved from https://scholar.google.co.id/citations?user=WikIX3sAAAAJ\&hl=id 